\title{
Development of a Web Based Inventory Information System
}

\author{
Johni S Pasaribu \\ Faculty of Engineering, Politeknik Piksi Ganesha, Bandung, Indonesia \\ *Corresponding author E-mail: johni_0106@yahoo.com
}

Manuscript received 23 Feb 2021; revised 2 March. 2021; accepted 15 March 2021. Date of publication 2 April 2021

\begin{abstract}
CV. T. Kardin Pisau Indonesia is a company engaged in the manufacture of knives, having its address at Jl. Hegarmanah No.46 Bandung. As a manufacturing company, CV. T. Kardin Pisau Indonesia needs to take advantage of information technology in warehouse inventory management, no longer in manual management, namely recording in paper media, which will be vulnerable to data mismatches. Web application here is defined as an inventory application, through displays which include items to be stored in the warehouse and incoming and outgoing product transactions. The research method used here is Research and Development (R\&D). Making software is done with a waterfall model which consists of stages: needs analysis, design, implementation, and testing. In object orientation paradigm modeling system with visual UML. The results of this study produce web-based software using the YII Framework with the MVC (Model View Controller) method. Through a web application that provides direct contact, it is hoped that the service process to consumers can be clear and fast. This inventory application can be used as material for product inventory in warehouse stock which includes recording, processing, and reporting data on warehouse inventory. Another benefit is that with this web-based application, the head office can know the inventory in the warehouse by itself so that it can quickly take action to fill the warehouse inventory.
\end{abstract}

Keywords: Web-based; Inventory; Warehouse; CV. T. Kardin Pisau Indonesia.

\section{Introduction}

The very rapid development of technology in the current era of globalization has provided many benefits in various aspects of life. Humans are starting to take advantage of technology to help complete work, including information technology [1]. Information technology which is increasingly rapidly can be used to improve the performance of a company. One example is information technology used for processing inventory data. Inventory management is a significant thing for product sales companies, where the company must be able to anticipate the number of products that are prepared. With the development of existing information technology, it can provide support to company managers with information and coordination about their products [2]. The use of a computerized system will save more time, do not consume a lot of energy, and result in the accuracy of data presentation [3].

Inventory-related problems are common problems that are often faced in the business sector [4]. Inventory problems that arise can be in the form of too much inventory or too little inventory to meet customer demand. The inventory function of goods in a warehouse is an activity consisting of data on incoming goods, data on goods that are out, and stock of items that are still there [5]. The amount of stock of goods that should be in the company and must be in accordance with the needs, not too much but not too little [6]. If it is too much, it will increase the capital requirement for investment, require a large storage area, and increase costs associated with the amount of goods stored. On the other hand, if there is too little, not all of the market share needs are fulfilled, so that the smooth operation of the transaction is disrupted. CV. T. Kardin Pisau Indonesia is a company engaged in manufacturing, namely the manufacture of knives in the city of Bandung. As a manufacturing company, the warehouse inventory at CV. T. Kardin Pisau Indonesia managed manually, which was recorded in paper media, which made the inventory inventory data inaccurate. This can result in losses if the stock of goods is less while the demand is high or the stock of goods is abundant while the demand is low. For this reason, it is necessary to take advantage of information communication technology (ICT) which is an integral part of the company [7]. The web-based software allows for centralized storage which can improve sales management. Thus, the product inventory manager can communicate with employees to obtain information and take action quickly and effectively [8]. Based on this, the author tries to design and create applications/software that can help existing business processes in the warehouse section of CV. T. Kardin Pisau Indonesia to make it faster and more accurate.

The problems that occur are:

1. CV. T. Kardin Pisau Indonesia had difficulty knowing the stock of goods and raw materials accurately.

2. CV. T. Kardin Pisau Indonesia had difficulty making stock reports. 
In designing this software program, in order to be more focused and easier to discuss, it is necessary to limit the problem. That is :

1. This software discusses the processing of raw material stocks.

2. Intended for warehouse employees.

3. Made with local Web-based.

4. The software is made with web programming languages: PHP, HTML, JavaScript, JQuery, CSS.

5. Database using MySQL.

6. Web Server using Apache.

The author's goal to make the software is to design software that is in accordance with the inventory management process that is in CV. T. Kardin Pisau Indonesia, which includes the following:

1. Reducing errors in data processing in and out of goods, so that the data is managed accordingly.

2. Make it easier for data processing in and out of goods to be more effective and efficient.

\section{Methods}

\subsection{Research Method}

The research method is a research method to obtain valid data with the aim of being able to find, develop, and prove certain knowledge so that it can be used to understand, solve, and anticipate problems in making or producing products to test the effectiveness of these products [9]. The software development approach in this research is the classic life cycle model or the waterfall model. According to [10], the waterfall model is a classic model with a systematic and sequential approach to the level of system progress in all analysis, design, code, testing, and maintenance. The waterfall development model used is combined with the prototyping paradigm to help make it easier for researchers to define user needs and anticipate changing needs in the software development process [11]. Prototyping is a technique that can be implemented in the context of other process models, although the prototyping paradigm can be used as a stand-alone process model [10]. Prototyping can help developers and users understand what to build first when requirements are still general. The phases in the Waterfall Model according to Sommerville's references [12] are as follows:

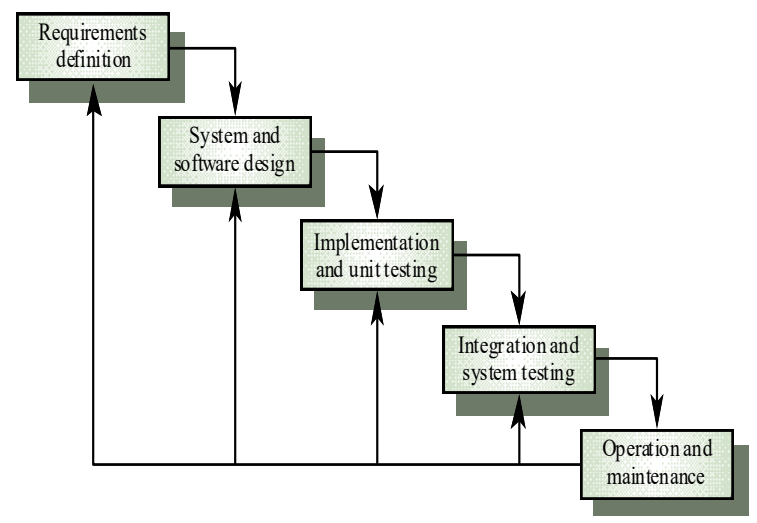

Fig 1. Waterfall Model Sommerville

\subsection{Procedural Design}

$\begin{array}{ll}\text { Module Name } & : \text { stock items } \\ \text { Purpose } & \text { Looking for the amount of net stock of goods after the demand at warehouse and the goods } \\ & \text { supply into warehouse } \\ \text { Input } & \text { initial stock } \\ & \text { Quantity of demand } \\ & \text { Quantity of supply } \\ & : \text { stock items } \\ \text { Output } & \text { If initial stock }=\mathrm{A}(\mathrm{t}) \\ \text { Algorithm } & \text { Quantity of demand }=\mathrm{B}(\mathrm{t}) \\ & \text { Quantityof incoming goods }(\operatorname{supply})=\mathrm{C}(\mathrm{t}) \\ & \text { Then the net stock }=\mathrm{A}(\mathrm{t})-\mathrm{B}(\mathrm{t})+\mathrm{C}(\mathrm{t})\end{array}$

\section{Results and Discussion}

\subsection{Context Diagram}

After the system requirements have been created, the next stage of the system development cycle is system design. At this stage, context diagrams and data flow diagrams are made. Context diagram illustrates the scope of the system. In this context diagram there is one entity, namely Admin. 


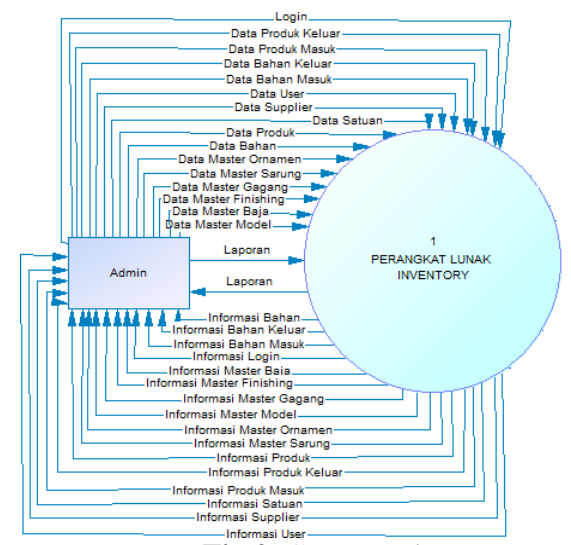

Fig 2. Context Diagram

\subsection{Data Flow Diagram}

Data flow diagram illustrates all the processes that exist in the system to be built.

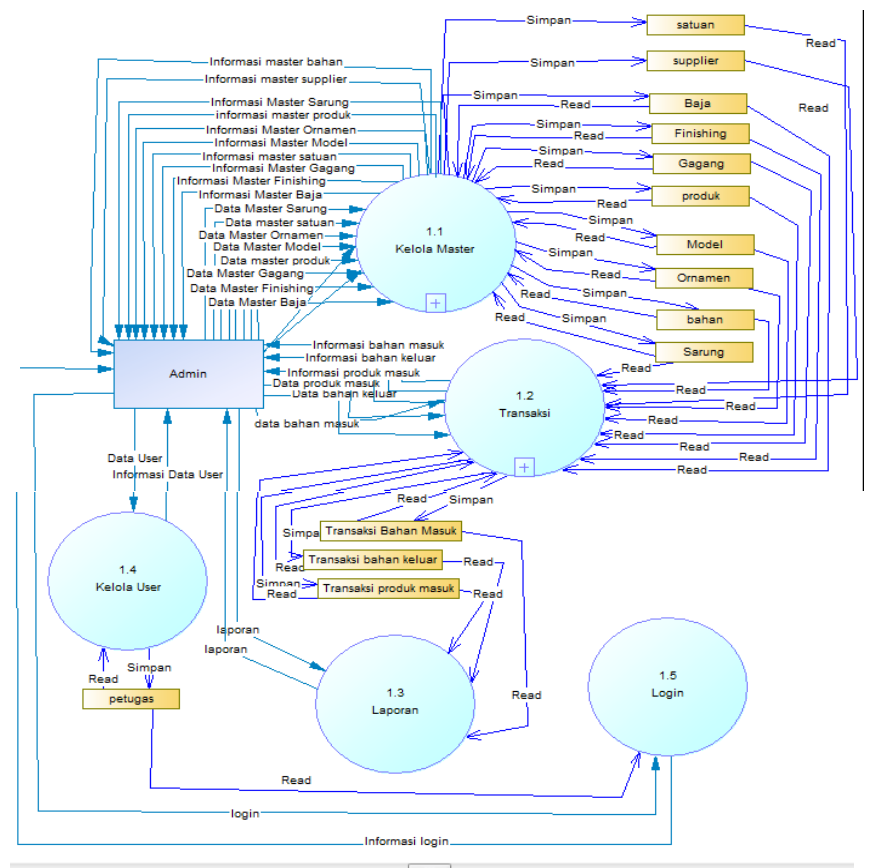

Fig 3. Data Flow Diagram

\subsection{System View}

The display or interface of this information system is as follows:

a. Dialog Screen: Login

Function: Used to enter the software

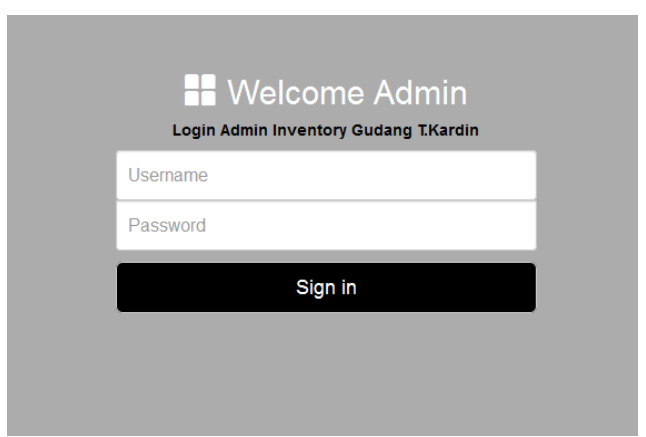

Fig 4. Display Login 
b. Dialog Screen: Dashboard

Function: Main menu display after login.

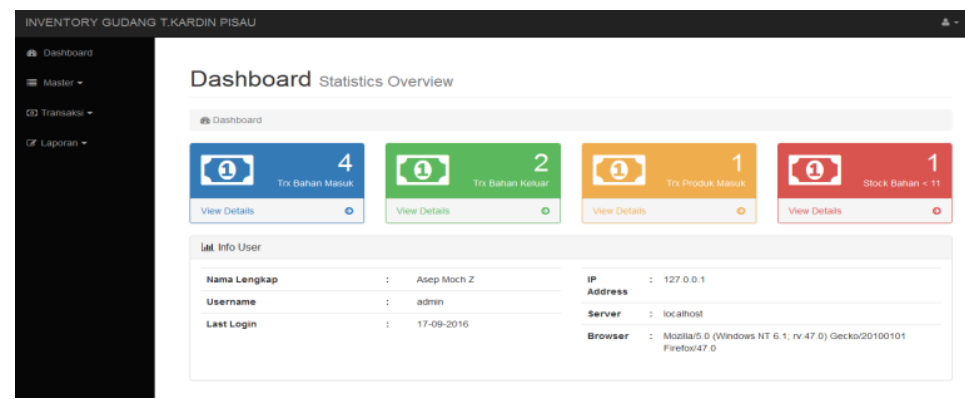

Fig 5. Dashboard

c. Dialog Screen: Data Model

Function: Manage model data. There is Add New Data button, Edit button and Delete button.
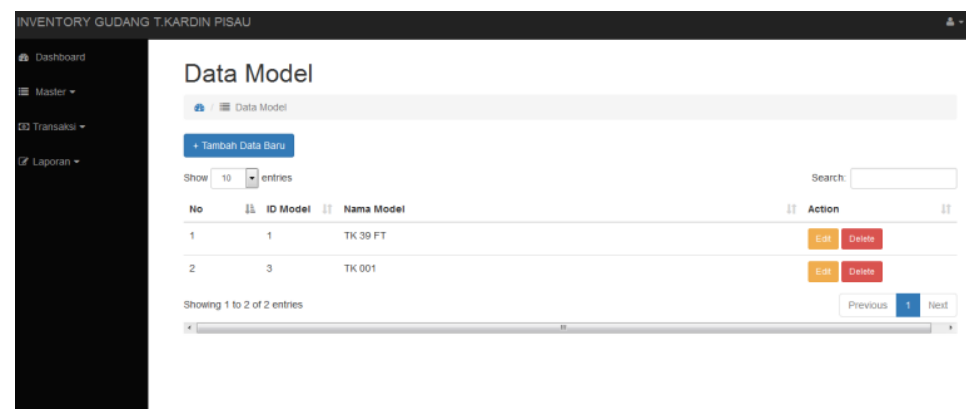

Fig 6. Data Model

c. Dialog Screen: Steel Data

Function: Manage steel data. There is Add New Data button, Edit button and Delete button.

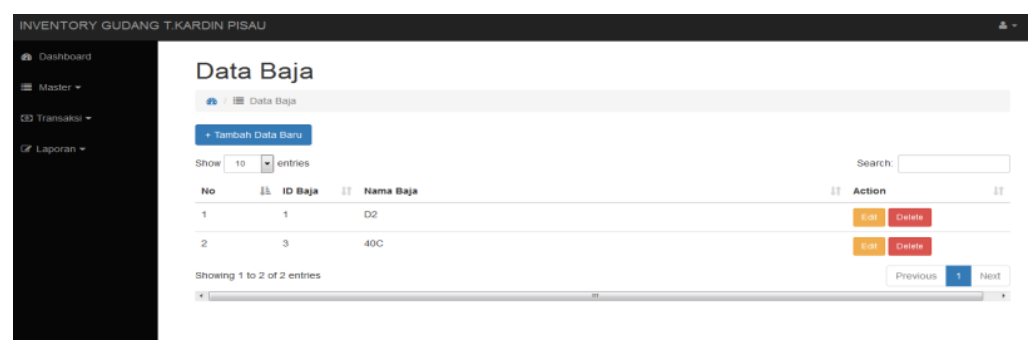

Fig 7. Steel Data

d. Dialog Screen: Hilt Data

Function: Manage hilt data. There is Add New Data button, Edit button and Delete button.

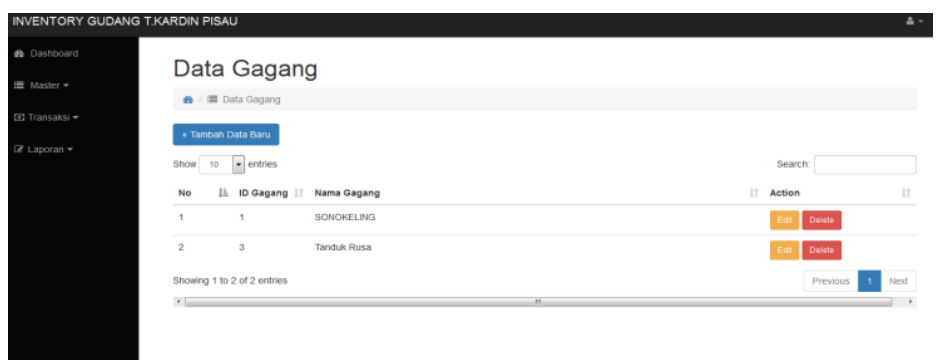

Fig 8. Data Flow Diagram

e. Dialog Screen: Scabbard Data

Function: Manage scabbard data. There is Add New Data button, Edit button and Delete button.

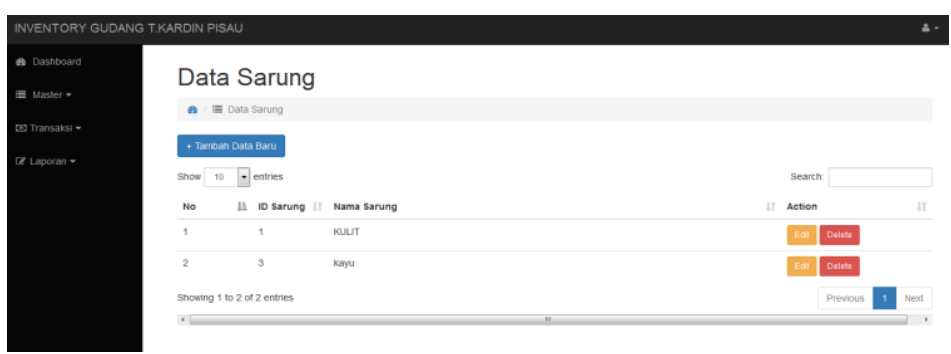

Fig 9. Scabbard Data 
f. Dialog Screen: Ornament Data

Function: Manage ornament data. There is Add New Data button, Edit button and Delete button.

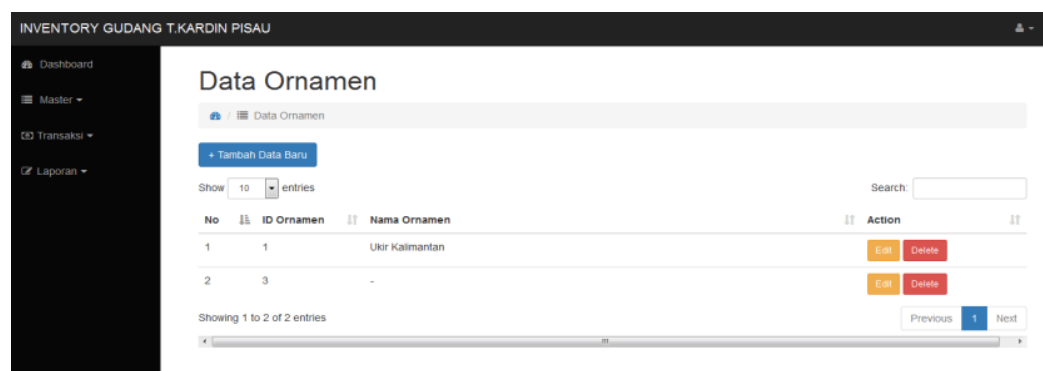

Fig 10. Ornamen Data

g. Dialog Screen: Finishing Data

Function: Manage finishing data. There is Add New Data button, Edit button and Delete button.

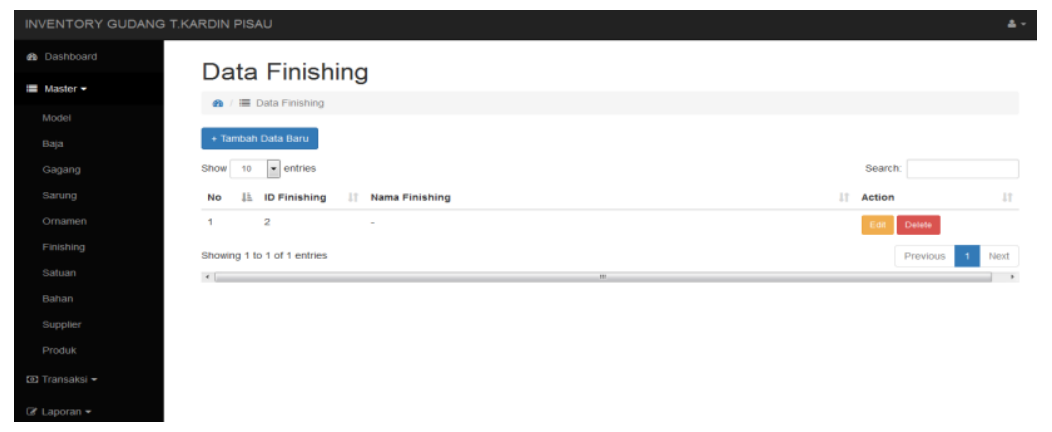

Fig 11. Finishing Data

h. Dialog Screen: Unit Data

Function: Manage unit data. There is Add New Data button, Edit button and Delete button.

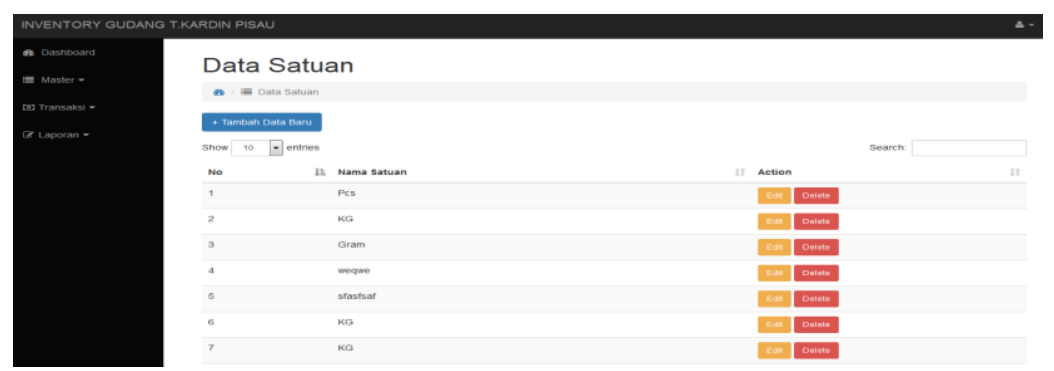

Fig 12. Unit Data

i. Dialog Screen: Material Data

Function: Manage material data. There is Add New Data button, Edit button and Delete button.

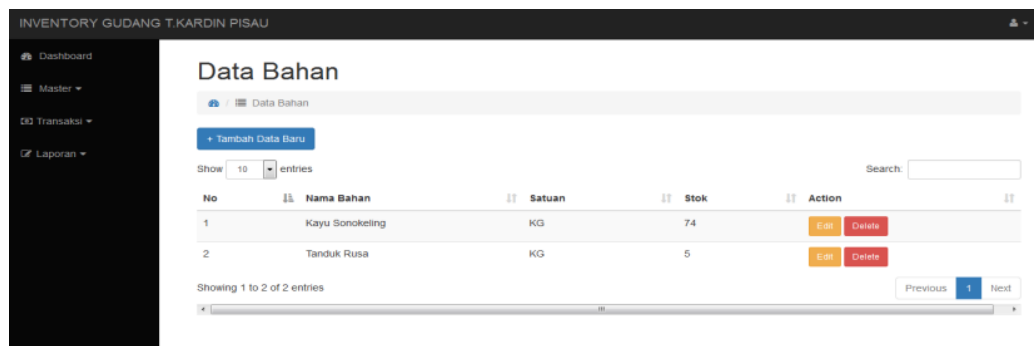

Fig 13. Data Flow Diagram

j. Dialog Screen: Supplier Data

Function: Manage supplier data. There is Add New Data button, Edit button and Delete button. 


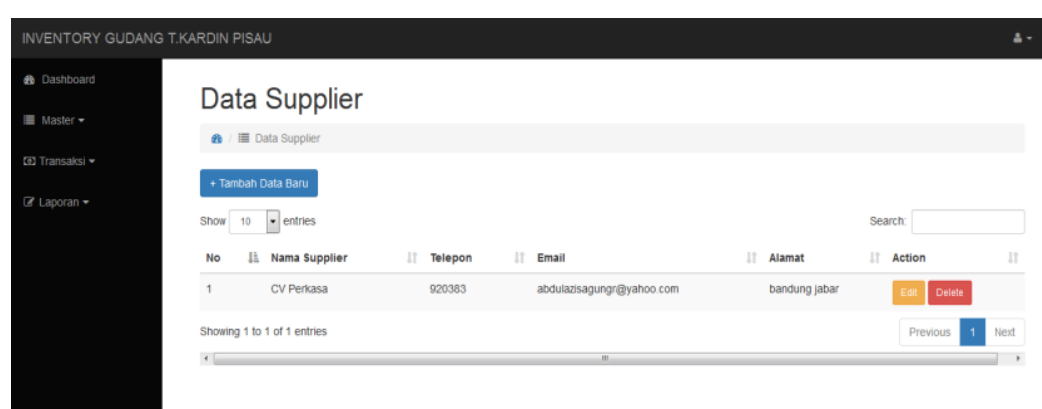

k. Dialog Screen: Blade Data

Fig 14. Data Flow Diagram

Function: Manage blade data. There is Add New Data button, Edit button and Delete button.

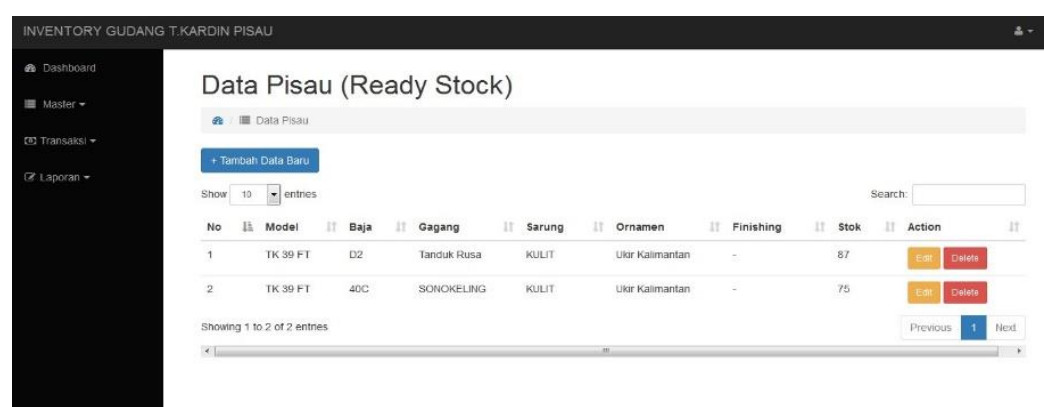

Fig 15. Blade Data

1. Dialog Screen: Incoming Material Transaction

Function: Manage incoming material transaction data. There is Add New Data button and Detail button.

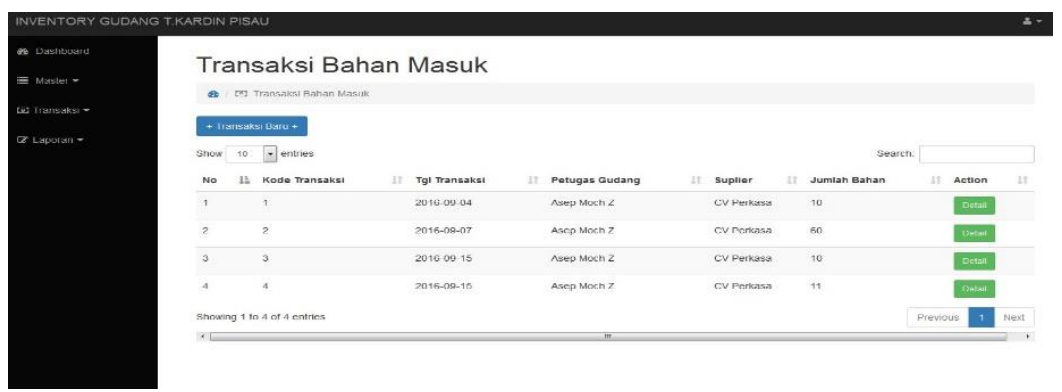

Figure 16. Incoming Material Transaction

m. Dialog Screen: Outgoing Material Transactions

Function: Manage outgoing material transaction data. There is Add New Data button and Detail button.

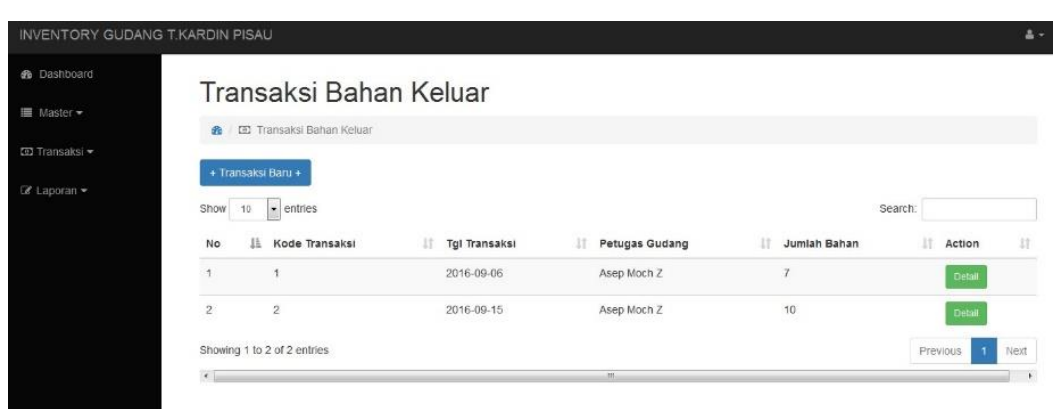

Fig 17. Outgoing Material Transaction

n. Dialog Screen: Incoming Product Transaction

Function: Manage incoming product transaction data. There is Add New Data button and Detail button. 


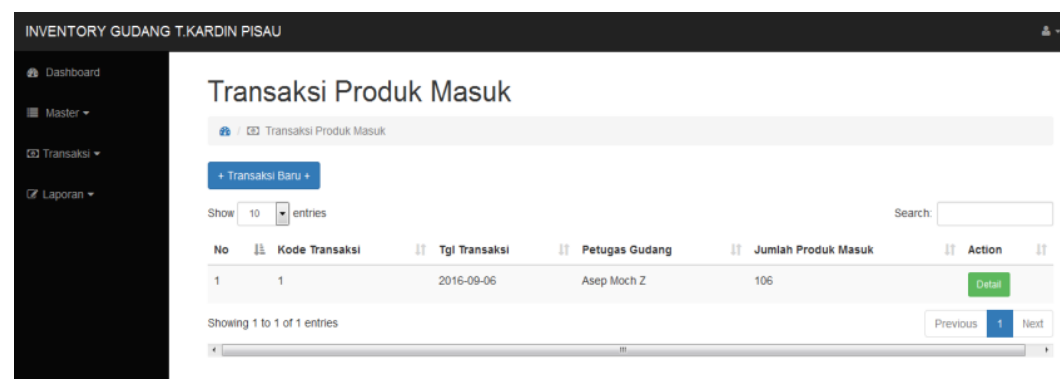

Fig 18. Outgoing Material Transaction

o. Dialog Screen: Material Stock Report

Function: Manage material stock report data. There is Add New Data button and Detail button.

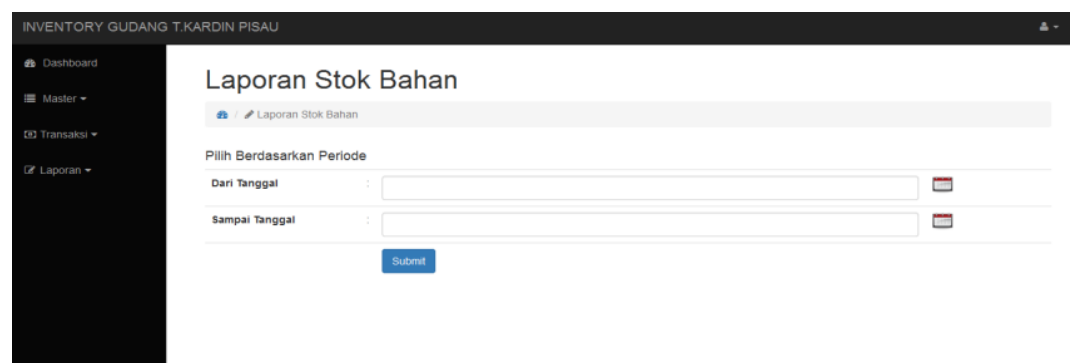

Fig 19. Material Stock Report

\section{Conclusion}

This web-based inventory information system can help users to get efficient and effective inventory management performance. This is because the existence of this inventory software can make it easier to record and process data on incoming and outgoing goods transactions, thereby increasing time efficiency.

This web-based inventory information system is very useful for companies because it makes easy to make reports so that it is very supportive of the company's mission, namely fast and accurate service.

\section{Acknowledgement}

The researcher would like to express his gratitude to Mr. Mochamad Asep Zainal as Production Manager at CV. T. Kardin Pisau Indonesia who has granted many research permits. The researchers also do not forget to thank fellow lecturers and study program leaders at Informatics Engineering, Politeknik Piksi Ganesha who always provide encouraging support.

\section{References}

[1] A. Pasaribu, J.S. \& Taryanto, "Implementasi Strategi E-Marketing Berbasis Web (Studi Kasus Perusahaan Katering dan Dekorasi)," E-Komtek, vol. 2 no 1, pp. 10-22, 2018, [Online]. Available: https://jurnal.politeknik-kebumen.ac.id/index.php/EKOMTEK/article/view/90.

[2] T. Kamphues, J. and Hegmanns, “A Modular Approach for Integrated Inventory Management in Distribution Logistics," IFACPapers Line, vol. 48 no 3, pp. 1815-1820, 2015, [Online]. Available: https://www.sciencedirect.com/science/article/pii/S2405896315005893.

[3] J. S. Pasaribu, "Penerapan Framework YII Metoda MVC Dalam Pembangunan Sistem PPDB Berbasis Web di SMP BPPI Baleendah Kabupaten Bandung," JITTER J. Ilm. Teknol. Inf. Terap., vol. 3 no. 2, 2017, [Online]. Available: http://journal.widyatama.ac.id/index.php/jitter/article/view/132/122.

[4] I. Myers, David; Dalgity, Alison \& Avramides, "The Arches Heritage Inventory and Management System for the Protection of Cultural Resources,” J. Cult. Herit. Manag. Sustain. Dev., vol. 6 no. 2, pp. 213-224, 2016, [Online]. Available: https://www.getty.edu/conservation/our_projects/field_projects/arches/JCHMSD_02_2016_Arches.pdf.

[5] D. 2019. Fadillah, A. P., \& Fitriana, "Design of Project Data Management Information System," IOP Conf. Ser. Mater. Sci. Eng., vol. 662, p. 022014, 2019, [Online]. Available: https://iopscience.iop.org/article/10.1088/1757-899X/662/2/022014.

[6] K. . G. Madamidola, O.A.; Daramola, O.A. and Akintola, "Web - Based Intelligent Inventory Management System," IJTSRD - Int. J. Trend Sci. Res. Dev., vol. 1(4), 2017, [Online]. Available: www.ijtsrd.com.

[7] J. Muyumba, Thomas and Phiri, "A Web based Inventory Control System using Cloud Architecture and Barcode Technology for Zambia Air Force," IJACSA Int. J. Adv. Comput. Sci. Appl., vol. 8 no. 11, pp. 132-142, 2017, [Online]. Available: https://thesai.org/Downloads/Volume8No11/Paper_17-A_Web_Based_Inventory_Control_System.pdf.

[8] S. P. Nama, G. F., Rasyidy, F. H., \& Arum, "A Real-time Schoolchild Shuttle Vehicle Tracking System Base on Android Mobileapps," IJET Int. J. Eng. \&Technology, vol. 7, pp. 40-44, 2018, [Online]. Available: https://www.researchgate.net/publication/333311693_A_Realtime_Schoolchild_Shuttle_Vehicle_Tracking_System_Base_on_Android_Mobile-apps.

[9] Sugiyono, Metode Penelitian Kuantitatif, Kualitatif, dan R\&D. Bandung: CV. Alfabeta, 2014. 
[10] R. S. Pressman, Rekayasa Perangkat Lunak (Pendekatan Praktisi) Buku 1, 7th ed. Yogyakarta: Andi Offset, 2012.

[11] A. Munnasar, N.M.A and Govardhan, "A Comparison Between Five Models Of Software Engineering," IJCSI Int. J. Comput. Sci., vol. vol 7, no, pp. 95-97, 2010, [Online]. Available: https://www.ijcsi.org/papers/7-5-94-101.pdf.

[12] J. S. Pasaribu, "Implementasi Sistem Pendukung Keputusan Menggunakan Logika Fuzzy untuk Penerimaan Beasiswa di Poltek Piksi Ganesha Bandung," Proceeding SENTIKA, https://fti.uajy.ac.id/sentika/publikasi/makalah/2016/25.pdf.

pp.

$80-89$,

2016 ,

[Online].

Available: 